This is the author's final, peer-reviewed manuscript as accepted for publication. The publisher-formatted version may be available through the publisher's web site or your institution's library.

\title{
Selenate-enriched urea granules are a highly effective fertilizer for selenium biofortification of paddy rice grain
}

Lakmalie Premarathna, Mike J. McLaughlin, Jason K. Kirby, Ganga M. Hettiarachchi, Samuel Stacey, and David J. Chittleborough

\section{How to cite this manuscript}

If you make reference to this version of the manuscript, use the following information:

Premarathna, L., McLaughlin, M. J., Kirby, J. K., Hettiarachchi, G. M., Stacey, S., \& Chittleborough, D. J. (2012). Selenate-enriched urea granules are a highly effective fertilizer for selenium biofortification of paddy rice grain. Retrieved from http://krex.ksu.edu

\section{Published Version Information}

Citation: Premarathna, L., McLaughlin, M. J., Kirby, J. K., Hettiarachchi, G. M., Stacey, S., \& Chittleborough, D. J. (2012). Selenate-enriched urea granules are a highly effective fertilizer for selenium biofortification of paddy rice grain. Journal of Agricultural and Food Chemistry, 60(23), 6037-6044.

Copyright: Copyright @ 2012 American Chemical Society

Digital Object Identifier (DOI): doi:10.1021/jł3005788

Publisher's Link: http://pubs.acs.org/doi/abs/10.1021/jf3005788

This item was retrieved from the K-State Research Exchange (K-REx), the institutional repository of Kansas State University. K-REx is available at http://krex.ksu.edu 
Selenate-enriched urea granules are a highly effective fertilizer for selenium biofortification of paddy rice grain

Lakmalie Premarathna $^{\dagger}$, Mike J. McLaughlin ${ }^{\dagger, \S}$, Jason K. Kirby ${ }^{\S}$, Ganga M. Hettiarachchi ${ }^{\ddagger \dagger}$, Samuel Stacey ${ }^{\dagger}$, and David J. Chittleborough ${ }^{\dagger, \&}$

$\dagger$ Soil Science, School of Agriculture, Food and Wine, Waite Research Institute, The University of Adelaide, Urrbrae, SA 5064, Australia.

${ }^{\S}$ CSIRO Land and Water, Environmental Biogeochemistry Program, Sustainable Agriculture Flagship, Waite Campus, Waite Road, Urrbrae, SA 5064, Australia.

* Department of Agronomy, Throckmorton Plant SciencesCentre, KansasStateUniversityManhattan, KS 66506 USA.

${ }^{\&}$ Geology and Geophysics, School of Earth and Environmental Sciences, North Terrace Campus, The University of Adelaide, SA 5005, Australia.

Corresponding Author: Ganga M. Hettiarachchi 
1 Selenate-enriched urea granules are a highly effective fertilizer for selenium

2 biofortification of paddy rice grain

3

\section{ABSTRACT}

5 We examined the effects of applied selenium (Se) species, time of application, method of

6 application and soil water management regime on accumulation of Se in rice plants. Plants

7 were grown to maturity in a temperature- and humidity-controlled growth chamber using

8 three water management methods: field capacity (FC), submerged until harvest, and

9 submerged and drained two weeks before harvest; two Se species: selenate $\left(\mathrm{SeO}_{4}^{-2}\right)$ and

10 selenite $\left(\mathrm{SeO}_{3}{ }^{-2}\right)$ applied at a rate equivalent to $30 \mathrm{~g} \mathrm{ha}^{-1}$; and four application methods: i) Se

11 applied at soil preparation, ii) Se-enriched urea granules applied to floodwater at heading iii)

12 foliar Se applied at heading and iv) fluid fertilizer Se applied to soil or floodwater at heading.

13 Total Se concentrations in rice grains, husks, leaves, culms and roots were measured, as well

14 as Se speciation in grains from the Se-enriched urea granule treatment. Highest Se

15 concentrations in the grain occurred with $\mathrm{SeO}_{4}{ }^{-2}$ and with fertilizer applied at heading stage;

$16 \mathrm{SeO}_{4}{ }^{-2}$-enriched urea granules applied at heading increased grain Se concentrations 5 to 6

17 fold (by 450-600 $\mu \mathrm{g} \mathrm{kg}^{-1}$ ) compared to the control (no fertilizer Se applied) in all water

18 treatments. Under paddy conditions other Se fertilization strategies were much less effective.

19 Drainage before harvesting caused Se to accumulate in/on rice roots, possibly through

20 adsorption onto iron plaque on roots. Rice grains contained Se mainly in the organic form as

21 selenomethionine $(\mathrm{SeM})$ which comprised over $90 \%$ of the total grain $\mathrm{Se}$ in treatments

22 fertilized with $\mathrm{SeO}_{4}{ }^{-2}$-enriched urea granules. The results of this study clearly show of the

23 fertilizer strategies tested that biofortification of Se in rice grains can best be achieved in 
24 lowland rice by broadcast application of $\mathrm{SeO}_{4}{ }^{-2}$-enriched urea granules to floodwater at 25 heading stage.

26 Keywords: selenium, selenite, selenate, biofortification, fertilizer, rice, Se enriched urea

\section{INTRODUCTION}

30 Selenium is an essential micronutrient for humans and animals $(1,2)$. Toxicity and deficiency

31 of Se in humans and animals is separated by a very narrow margin compared to other 32 nutrients (3). Low dietary intake of Se causes health problems including low immunity, 33 oxidative stress related conditions, reduced fertility and cancer (1). Different strategies have

34 been tested or implemented worldwide in order to achieve optimum Se concentrations in 35 humans (3), the most common strategies include the consumption of high-Se foods (e.g., 36 Brazil nuts), individual supplementation, Se supplementation to livestock (4), and 37 biofortification of food crops (4-6).

39 Biofortification is the increase in the bioavailable concentration of elements in edible portions 40 of crop plants through either fertilization (agronomic biofortification) or crop selection and 41 breeding (genetic biofortification) (4-6). Agronomic biofortification is an easy and cheap 42 method to increase Se concentrations in edible portions of crops (7). Selenium fertilizer 43 programs have successfully been implemented in Finland for forage and cereal crops and 44 increased Se concentrations in animals and human population have been achieved (5). In 45 Finland the Se intake per capita has increased from $25 \mu \mathrm{g} \mathrm{d}^{-1}$ to $124 \mu \mathrm{g} \mathrm{d}^{-1}$ (5). Increasing the

46 Se concentration in foods such as wheat and rice is an appropriate target to increase human 47 Se intake because they are the staples for most of the world's population. Selenium fertilizer 
programs have been developed for wheat but no effective Se program has yet been developed

49 for rice.

51 Rice can be grown in upland or lowland conditions, and different fertilization strategies may

52 be needed for each scenario, both in terms of Se species used and method of fertilizer 53 application (foliar or applied to soil). The availability of soil applications of Se are often 54 much greater under upland conditions compared to flooded soils $(8,9)$, but the majority of 55 rice crops around the world are lowland cultivated (10). In terms of the most effective Se 56 species, for foliar applications $\mathrm{SeO}_{4}{ }^{-2}$ has been found to be more effective than $\mathrm{SeO}_{3}{ }^{-2}$ for $\mathrm{Se}$ 57 biofortification of rice (6). There are no data to evaluate the effectiveness of soil-applied $58 \mathrm{SeO}_{3}{ }^{-2}$ or $\mathrm{SeO}_{4}{ }^{-2}$ for biofortification of rice, but these species appear to be equally available to 59 wheat plants under aerobic conditions in solution culture (1). However, in aerobic soils 60 addition of $\mathrm{SeO}_{4}{ }^{-2}$ often leads to greater accumulation of Se in plants than $\mathrm{SeO}_{3}{ }^{-2}(11,12)$, 61 likely due to greater retention of $\mathrm{SeO}_{3}{ }^{-2}$ by soils $(11,13,14)$. Developing a Se fertilization program for lowland rice is challenging because soil-applied Se availability depends on redox

63 and $\mathrm{pH}$ conditions in submerged soils. Availability to rice of soil-applied $\mathrm{SeO}_{4}^{-2}$ fertilizer in 64 flooded soils has been found to be low $(9,15)$, either due to reduction to $\mathrm{SeO}_{3}{ }^{-2}$, which is 65 more strongly retained by soils than $\mathrm{SeO}_{4}{ }^{-2}(13,16)$, or to reduction of Se oxyanions to 66 elemental $\mathrm{Se}(0)$ in anoxic soils (17). Hence, foliar Se fertilization of crops is often preferred 67 (18) and has been tested on rice $(19,20)$. However, the disadvantages of foliar fertilization are the additional labour involved in separately applying Se from other broadcast granule 69 applied nutrient, as well as the lack of any residual effect for subsequent crops. An effective 70 alternative fertilization strategy for $\mathrm{Se}$ where macronutrients (nitrogen, phosphorus or 71 potassium) are applied simultaneously with Se would therefore be advantageous. 
73 Previously we showed that the potential availability of soil-applied $\mathrm{SeO}_{4}{ }^{-2}, \mathrm{SeO}_{3}{ }^{-2}$ and $\mathrm{Se}(0)$

74 differed markedly in both aerobic and anaerobic soils (21). Application of Se fertilizers in

75 any form during soil preparation was ineffective because Se availability (as determined by

76 isotopic dilution) decreased rapidly after soil flooding (22). Pre-harvest oxidation of paddy

77 soil is likely to release little available Se due to the slow oxidation of both $\mathrm{Se}(0)$ to $\mathrm{SeO}_{3}{ }^{-2}$,

78 and also slow oxidation of $\mathrm{SeO}_{3}{ }^{-2}$ to $\mathrm{SeO}_{4}{ }^{-2}$ (23). Hence a more effective Se fertilization

79 strategy is required.

81 Bioavailability of Se for humans and animals largely depends on the species of Se consumed

82 rather than the total Se concentration. Organic Se species in the diet are more bioavailable

83 than inorganic Se species $(24,25)$. Organic Se compounds such as methylselenocysteine

84 (MeSeCys), selenomethionine (SeM) and $\gamma$-glutamyl-Se-methylselenocysteine ( $\gamma$-glutamyl-

85 MeSeCys) are effective chemo-protective agents which may prevent the development of

86 breast, liver and prostate cancers $(24,26)$ but there is a paucity of studies on the organic and

87 inorganic Se species present in rice grains following application of different Se fertilizers to 88 plants or soils.

90 Here we report experiments to elucidate the effect of Se species, time of application, soil

91 water regime and four Se application methods on the yield of rice and the accumulation of Se

92 in grains, culms, leaves and roots under both upland and paddy growth conditions. The

93 speciation of $\mathrm{Se}$ in grains from the $\mathrm{SeO}_{4}{ }^{-2}$-enriched urea granule treatment was further

94 undertaken to examine the effect of increased Se accumulation on Se species present in 95 grains.

97 MATERIALS AND METHODS 


\section{Standards and reagents}

100 - All reagents and standards used were of trace metal grade and ultrapure deionised

101 water (Milli-Q, Millipore) was used for all chemical preparations and dilutions. Sodium salts

102 of sodium selenite and sodium selenate, SeM, and citric acid were purchased from Sigma

103 (Australia). Individual stock solution of $\mathrm{SeO}_{3}{ }^{-2}$ at $1000 \mathrm{mg} \mathrm{Se} \mathrm{L}^{-1}$ was purchased from SPEX-

104 Certiprep, USA. Selenomethionine selenoxide (SeOM) was prepared through the addition of

105 excess hydrogen peroxide $\left(0.1 \mathrm{~mL}\right.$ of $\left.30 \% \mathrm{H}_{2} \mathrm{O}_{2}\right)$ to $2 \mathrm{~mL}$ of $\mathrm{SeM}\left(100 \mathrm{mg}\right.$ of $\left.\mathrm{Se} \mathrm{L}^{-1}\right)(27)$.

106

107 Pot experiment 1

108 Plants were grown in $3.5 \mathrm{~L}$ black plastic pots lined with plastic bags and filled with $2 \mathrm{~kg}$ of

109 the Hanwood loam (a Rodoxeralf (37)) collected near Griffith, a rice growing area of

110 Australia. The soil had a pH 6.36 (1:5 soil: water suspension) (28), EC $141.2 \mu \mathrm{S} \mathrm{cm}{ }^{-1}$ (28),

111 total carbon $2 \%$ (29), cation exchange capacity (CEC) $21 \mathrm{cmol}(+) \mathrm{kg}^{-1}$ and a total Se

112 concentration of $0.117 \mathrm{mg} \mathrm{kg}^{-1}$. All pots received the equivalent of $150 \mathrm{~kg} \mathrm{~N} \mathrm{ha}^{-1}$ (half

113 applied at soil preparation and half at the heading stage), $25 \mathrm{~kg} \mathrm{P} \mathrm{ha}^{-1}$ and $100 \mathrm{~kg} \mathrm{~K} \mathrm{ha}^{-1}$,

114 together with a micronutrient mix of $0.3 \mathrm{ZnSO}_{4}, 0.3 \mathrm{CuSO}_{4}, 0.1 \mathrm{H}_{3} \mathrm{BO}_{3}, 20 \mathrm{CaSO}_{4}, 20$

$115 \mathrm{MgSO}_{4}$ and $0.01\left(\mathrm{NH}_{4}\right)_{6} \mathrm{Mo}_{7} \mathrm{O}_{2} 4 \mathrm{H}_{2} \mathrm{O} \mathrm{kg} \mathrm{ha}{ }^{-1}(30)$ applied during soil preparation. Soils were

116 either submerged or maintained at FC for $14 \mathrm{~d}$ before transplanting two eighteen day old

117 healthy rice seedlings (Oryza sativa sp. Amaroo). Two weeks before harvest, submerged

118 treatments were drained and moisture content was thereafter maintained at FC. Plants were

119 grown until final harvest at physiological maturity. 


\section{Treatments and experiment design}

122 The experiment was conducted in a light-, temperature-, and humidity-controlled growth

123 chamber. Maximum and minimum temperatures inside the growth chamber were $30^{\circ} \mathrm{C}$ and $12425^{0} \mathrm{C}$ and $12 \mathrm{~h}$ daylight cycle with high humidity (53\%). There were 81 pots in a randomized 125 complete block design with a factorial arrangement of the treatments; two Se species; i.e. $126 \mathrm{SeO}_{3}{ }^{-2}$ and $\mathrm{SeO}_{4}{ }^{-2}$, three water treatments; i.e. field capacity, submerged and submerged then 127 drained; and four application methods (see below).

\section{Application of selenium fertilizer}

130 Rate of Se application was equivalent to $30 \mathrm{~g} \mathrm{ha}^{-1}$ based on application rates used in previous

131 studies (31) and assumptions regarding loss of Se by sorption to soil. Selenite and $\mathrm{SeO}_{4}{ }^{-2}$

132 fertilizers were added to soil either at soil preparation or heading stage. Selenium applied as 133 either $\mathrm{SeO}_{4}{ }^{-2}$ or $\mathrm{SeO}_{3}{ }^{-2}$ at soil preparation was sprayed as a dilute solution of sodium selenite 134 or sodium selenate diluted in ultrapure deionised water (Milli-Q, Millipore) onto the soil and 135 mixed thoroughly. At the heading stage either $\mathrm{SeO}_{4}{ }^{-2}$ or $\mathrm{SeO}_{3}{ }^{-2}$ was applied by 3 methods;

$136 \mathrm{SeO}_{4}{ }^{-2}, \mathrm{SeO}_{3}{ }^{-2}$-enriched urea granules or fluid Se fertilizer was applied to the soil surface. The 137 Se-enriched urea was prepared by spraying Se (sodium selenite or sodium selenate in high 138 purity deionized water solution) onto the urea granules and letting the granules to dry at $30{ }^{\circ} \mathrm{C}$ 139 in an oven. The fluid Se fertilizer was a solution of either sodium selenite or sodium selenate 140 in high purity deionised water. Foliar $\mathrm{SeO}_{4}{ }^{-2}$ or $\mathrm{SeO}_{3}{ }^{-2}$ fertilizer was of either sodium selenite 141 or sodium selenate in high purity deionised water and was sprayed carefully onto leaves using 142 aerosol sprayers at heading stage. Pots receiving the foliar fertilizer at heading were separated 143 from other treatments to avoid contamination during spraying. 


\section{Rice sample preparation for analysis}

146 At maturity, plants were harvested and shoots, roots and grains were separated. Roots were 147 cleaned using reverse osmosis (RO) water, $1 \%$ sodium lauryl sulphate $\left(\mathrm{CH}_{3}\right.$

$\left.148\left(\mathrm{CH}_{2}\right)_{10} \mathrm{CH}_{2} \mathrm{OSO}_{3} \mathrm{Na}\right)$ (Sigma) and finally in high purity deionised water. Plant samples

149 (grain, leaf, culm and root) were dried at $55^{\circ} \mathrm{C}$ to a constant weight and dry weight recorded

150 (grain). Husks were removed from harvested grains using a laboratory-scale hand operated 151 de-hulling machine. The plant tissues were ground using a laboratory seed grinder and sieved 152 to $<500 \mu \mathrm{m}$.

153

\section{Total Se analysis}

155 The grain samples were digested using a closed vessel microwave procedure (Ethos E touch 156 control, Milestone, North America) using a two-stage time program: $5 \mathrm{~min}$ at $300 \mathrm{~W}$ and 40 $157 \mathrm{~min}$ at $500 \mathrm{~W}$. Approximately $0.5 \mathrm{~g}$ of finely ground grain samples were weighed into a 158 Teflon digestion vessels and $10 \mathrm{~mL}$ of concentrate $\mathrm{HNO}_{3}$ acid (Aristar) added. After 159 microwave digestion, the vessels were allowed to cool for 30 minutes at room temperature 160 and then diluted to $50 \mathrm{~mL}$ with ultrapure deionised water (Milli-Q, Millipore). Digest 161 solutions were filter to $<0.22 \mu \mathrm{m}$ (Sartorius) and analysed for total Se concentrations by 162 inductively coupled plasma-mass spectrometry (ICP-MS) (Agilent 7500ce ICP-MS with $\mathrm{H}_{2}$ 163 gas added to the collision cell at a flow rate of $4 \mathrm{~mL} \mathrm{~min}^{-1}$ ). The accuracy of the digestion and 164 ICP-MS analysis procedure were assessed through the analysis of certified reference 165 materials NIST 1568a rice flour and NIST 1573a tomato leaves. The total Se concentrations 166 determined in the rice and tomato certified reference material were in close agreement with 167 the certified value (NIST $1568 \mathrm{a}$ - this study $0.38 \pm 0.04 \mathrm{mg} \mathrm{Se} \mathrm{kg}^{-1}(\mathrm{n}=3)$, certified value $=$

$1680.38 \pm 0.04 \mathrm{mg} \mathrm{Se} \mathrm{kg}^{-1} \mathrm{NIST} 1573 \mathrm{a}$ - this study $0.054 \pm 0.003 \mathrm{mg} \mathrm{Se} \mathrm{kg}^{-1}(\mathrm{n}=3)$; certified 169 value $=0.054 \pm 0.006)$ 


\section{Enzymatic extraction of selenium species for chromatographic speciation}

172 Approximately $0.2 \mathrm{~g}$ of ground grain tissue from the $\mathrm{SeO}_{4}{ }^{-2}$-enriched urea granule treatments 173 were weighed into $15 \mathrm{~mL}$ Pyrex culture tubes with $20 \mathrm{mg}$ protease XIV (Sigma) and $6 \mathrm{~mL}$ of 174 ultrapure deionised water (Milli-Q, Millipore). The samples were shaken end over end at $37^{0}$

$175 \mathrm{C}$ in an incubator for $24 \mathrm{hrs}$, centrifuged at $1200 \mathrm{~g}$ and filtered through a $0.22 \mu \mathrm{m}$ filter. The 176 resulting solutions were analyzed for Se species (OSeM, $\mathrm{SeO}_{4}{ }^{-2}, \mathrm{SeM}$ and $\mathrm{SeO}_{3}{ }^{-2}$ ) by high 177 performance liquid chromatography-inductively coupled plasma-mass spectrometry (HPLC178 ICP-MS) (32). The operating conditions for HPLC-ICP-MS are summarized in Table 1. The 179 identification of Se species occurred through retention time comparisons with synthetic 180 standards and concentrations were determined using peak areas..

\section{Pot experiment 2}

183 A second experiment was performed to examine uptake of Se from $\mathrm{SeO}_{4}{ }^{-2}$-enriched urea 184 granules and pure seleno-urea $\left(\mathrm{CH}_{4} \mathrm{~N}_{2} \mathrm{Se}\right)$. Environmental and soil conditions were identical

185 to those outlined above for pot experiment 1 , and treatments consisted of either $\mathrm{SeO}_{4}{ }^{-2}$ 186 enriched urea granules, $\mathrm{SeO}_{4}^{-2}$-enriched urea-ammonium nitrate (UAN) or pure seleno-urea. 187 At rice heading stage, Se fertilizers were applied onto floodwater in a similar manner to the 188 first experiment.

190 Floodwater samples were collected from 1-2 cm above the soil water interface at 1 and $10 \mathrm{~d}$ 191 after Se fertilizer application. At each sampling time, $10 \mathrm{~mL}$ of floodwater was collected 192 between two rice plants and filtered into centrifuge tubes using $0.22 \mu \mathrm{m}$ filters (Millipore 193 millex-GS). The floodwater solutions were acidified with $50 \mu \mathrm{L}$ of $6 \mathrm{M} \mathrm{HCl}$ and analysed for 194 total Se concentration using ICP-MS. 
196 Plant sap sample collection was undertaken following the method used by Li et al. (33).

197 Shoots were cut from $3 \mathrm{~cm}$ above the water level. The cut surface was washed using ultrapure

198 deionised water and blot dried with clean tissues before sap samples were collected for two

199 hours. Total Se concentrations in sap samples were determined using ICP-MS.

\section{Statistical analysis}

202 The significance of fertilizer applied Se species, application time, application method, and 203 soil water management on grain dry yield (grain) and Se concentrations in rice tissues (grain, 204 leaves, culm, and roots) were determined using analysis of variance (ANOVA) in Genstat 205 software (Genstat $10^{\text {th }}$ ed, VSN International, Hempstead, UK). Least significant differences 206 (LSD) were used for comparison of the treatment means.

\section{RESULTS AND DISCUSSION}

\section{Treatment effects on grain yield}

211 Rice plants growing in aerobic soil (FC) had lower grain dry weights than the other water

212 treatments $(\mathrm{p} \leq 0.05)$ with little or no effect of Se species or application method 213 (Supplementary information, Table 1). The reason for higher DW in grains from submerged 214 and submerged-drained treatments could be the availability of some nutrients in FC soils

215 being lower than submerged soils (Supplementary information, Table 2). We did not measure 216 nutrients in flood water for this study, however as other studies have reported elsewhere, 217 stabilization of $\mathrm{pH}$ around neutrality in submerged rice soils has some implications for the 218 availability of nutrients (34). In addition, the ability of the rice plant to grow under aerobic 219 conditions is often less (22). In particular, soil solution concentrations of $\mathrm{P}$, and $\mathrm{K}$, normally 
220 increase with submergence (10). These are essential nutrients for root development and 221 tillering (10) which ultimately determine final yield. Method of Se application had little consistent effect on grain yields, except in FC treatments where the control was significantly

223 lower than Se fertilizer treatments.

225 Treatment effects on Se accumulation in rice plants

\section{Grain and husk selenium accumulation}

227 Concentrations of Se in rice grains and husks under different treatments are shown in Table 2.

228 The largest part of the variance in Se concentrations was explained by application method 229 and Se species, and their interaction (Table 3). Overall, $\mathrm{SeO}_{4}{ }^{-2}$ treatments led to highest $\mathrm{Se}$ 230 concentrations in grains while $\mathrm{SeO}_{3}{ }^{-2}$ treatments led to the lowest grain concentrations. 231 However, the 3-way interaction of Se application method $\times$ applied Se species $\times$ water treatment was significant for both grain and husk Se concentrations $(\mathrm{p} \leq 0.001)$. Selenium applied at the heading stage led to higher grain Se than Se applied at soil preparation. Perhaps, at heading stage, plants are more physiologically active and mobilizing nutrients to fill the grains with photosynthetic products faster. Also, by heading stage, plant roots were well developed and well distributed ready for nutrient uptake. Furthermore, Se applied at soil preparation had two weeks without plants and, by the time plants were introduced into the pots, $\mathrm{Se}$ added as $\mathrm{SeO}_{3}{ }^{-2}$ would have been sorbed onto/into soil colloids/minerals and also $\mathrm{SeO}_{4}{ }^{-2}$ may have been reduced (22). By the time the root system of transplanted rice was ready for nutrient uptake, most of the added Se may have been converted to unavailable

241 forms such as selenide $\left(\mathrm{Se}^{-2}\right)$ or elemental selenium $(\mathrm{Se}(0))$.

243 The highest grain Se concentration was recorded for $\mathrm{SeO}_{4}{ }^{-2}$-enriched urea granules applied at 244 heading stage for all water treatments. In $\mathrm{FC}$ soils, fluid $\mathrm{SeO}_{4}{ }^{-2}$ applied at heading also had a 
statistically similar effect on accumulating Se in grains. It was expected to find higher grain

246 Se concentrations in the fluid $\mathrm{SeO}_{4}{ }^{-2}$ treatment applied at heading in FC treatments because

$247 \mathrm{SeO}_{4}^{-2}$ has been shown to be highly available in aerobic soils (35-38). In addition, studies on

248 upland crops such as wheat and barley have also recorded higher grain Se concentrations with

249 soil-applied $\mathrm{SeO}_{4}{ }^{-2}$ than $\mathrm{SeO}_{3}{ }^{-2}(4,39)$.

251 When Se was applied to soil at planting, drainage of floodwater before harvest had no effect on increasing Se concentrations in grain, suggesting that oxidation of any reduced Se species in soil to $\mathrm{SeO}_{4}{ }^{-2}$ was too slow to influence crop Se accumulation.

Foliar application at the heading stage gave the highest grain Se concentration $\left(0.27 \mathrm{mg} \mathrm{kg}^{-1}\right)$ for those plants received $\mathrm{SeO}_{3}{ }^{-2}$ in $\mathrm{FC}$ soils. In a study conducted in China examining foliar application of Se in paddy rice, researchers reported Se concentrations of 0.355 and $0.411 \mathrm{mg}$ $\mathrm{kg}^{-1}$ for two different varieties given $\mathrm{SeO}_{3}{ }^{-2}$ at a rate of $18 \mathrm{~g} \mathrm{ha}^{-1}(40)$. In another study, a rate of $20 \mathrm{~g} \mathrm{ha}^{-1}$ of $\mathrm{SeO}_{3}^{-2}$ led to a grain Se concentration of $0.471 \mathrm{mg} \mathrm{kg}^{-1}$ (19). However in our study, grain Se concentration in submerged pots with foliar $\mathrm{SeO}_{3}{ }^{-2}$ was far below to those

261 values (Table 2). In another submerged field trial, testing for $\mathrm{SeO}_{3}{ }^{-2}$ foliar spray showed that 262 in order to achieve $40-75 \mu \mathrm{g} \mathrm{kg}^{-1} \mathrm{Se}$ in rice grains, the solution should contain $20-30 \mu \mathrm{g} \mathrm{Se} \mathrm{\textrm {L } ^ { - }}$

$263^{1}$ (41). These values cannot be compared with our data because there was no information 264 given about how much solution was sprayed per plant or area and also no information on 265 whether they considered the Se concentrations in control pots not receiving Se fertilizer. 266 Possible reasons for the different Se values among different researches could be varietal 267 differences (7) and time remaining until harvest after fertilizer application. For instance, in 268 the study undertaken by $\mathrm{Hu}$ et al. (40), plants had $\sim 3$ months after fertilizer application at 
heading until harvest, at which stage the plants had a long time to transfer Se from leaf to grains. In our study, the elapsed time was a little over one month from heading to harvest.

272 Selenium accumulation in husks was generally lower than that of grain. Selenate-enriched 273 urea granules and fluid $\mathrm{SeO}_{4}^{-2}$ applied at heading had similar husk Se concentrations in 274 aerobic soils, but $\mathrm{SeO}_{4}{ }^{-2}$-enriched urea granule treatment was much more effective than all 275 other treatments in accumulating Se in rice husks in submerged and submerged/drained 276 treatments (Table 2). Overall, $\mathrm{SeO}_{4}{ }^{-2}$-enriched fertilizers were more effective than $\mathrm{SeO}_{3}{ }^{-2}$ 277 enriched fertilizers in increasing husk Se concentrations.

\section{Selenium accumulation in leaves and culms}

280 The three way interaction among applied Se species, application time, and method of 281 application were statistically significant $(\mathrm{p} \leq 0.001)$. However, interaction effects between Se application methods $\times$ applied Se species had significant and major effects on leaf Se concentration $(\mathrm{p} \leq 0.001)$. Highest leaf Se concentrations were for foliar applied Se in all soils (Table 4), likely due to retention of foliarly applied Se to leaf surfaces. As observed for grain $\mathrm{Se}$ data, $\mathrm{SeO}_{4}{ }^{-2}$-enriched urea granule treatments also had high $\mathrm{Se}$ concentrations in leaves and culms, and in this case the Se must have derived from root uptake.

\section{Selenium accumulation in/on roots}

By far the greatest proportion of the variation in Se concentrations in roots was explained by water management method with FC soils having the lowest root Se concentrations and submerged/drained soils the highest (Table 5). Even though the roots were thoroughly

292 cleaned before analysis, we cannot be certain whether this accumulation occurred inside the roots or on the root surface, as we observed iron plaque on the roots of submerged plants. 
294 Iron plaque is known to strongly sorb oxyanions $(42,43)$ and it is therefore highly likely that

$295 \mathrm{SeO}_{3}{ }^{-2}$ and/or $\mathrm{SeO}_{4}{ }^{-2}$ sorbed to the iron plaque.

\section{Selenium application method}

298 Application of fertilizer Se to soil prior to planting was ineffective possibly due to reactions

299 of $\mathrm{Se}$ in submerged soils that reduced the availability of both $\mathrm{SeO}_{3}^{-2}$ and $\mathrm{SeO}_{4}{ }^{-2}$ (21).

300 Application of $\mathrm{Se}$ at heading to the floodwater appears to be the most effective

301 biofortification strategy, and $\mathrm{SeO}_{4}{ }^{-2}$ was generally more effective than $\mathrm{SeO}_{3}{ }^{-2}$ in this regard.

302 There was no consistent advantage of foliar Se over fluid Se fertilizer applied to the

303 floodwater. However, it is evident from the results that the application of $\mathrm{SeO}_{4}{ }^{-2}$-enriched

304 urea granules to flood water at heading is a very promising way to deliver Se to paddy rice to

305 stimulate Se biofortification of grains. There are several possible mechanisms to explain the

306 efficiency of this treatment. The presence of $\mathrm{N}$ fertilizer (urea, mostly in the form of $\mathrm{NH}_{4}{ }^{+}$in

307 rice soils) may have influenced absorption of Se from the root mat at the soil surface, as after

308 application to flood water the Se-coated urea granules sank onto the exposed rot mat at the

309 interface of the soil and floodwater. Plant roots exposed to high $\mathrm{NH}_{4}{ }^{+}$or urea have the

310 potential to absorb more anions $(44,45)$. Alternatively, there may be more efficient

311 translocation of Se inside the plant when Se is applied with urea. Efficient translocation of Fe

312 in the presence of $\mathrm{N}$ fertilizer in wheat plants has been shown previously (46). Higher leaf Se

313 concentrations in the submerged treatments receiving Se-enriched urea granules, compared to

314 those receiving fluid Se, lends support to the idea of efficient translocation of Se when Se is

315 co-applied/co-located with urea. It should be noted however, that the fluid Se treatments also

316 received urea, although in this case the Se and urea were not co-located. A third hypothesis

317 was that Se applied with urea may have reacted to form selenourea $\left(\mathrm{CH}_{4} \mathrm{~N}_{2} \mathrm{Se}\right)$ in the granules

318 or at the soil/floodwater interface, and this enhanced the absorption of Se by the roots. Very 
319 little is known on the formation and reactions of selenourea in soils. Sorption of selenourea to

320 iron hydroxides is much less than that of selenite (47) and it is know that selenourea forms in

321 reduced environments (48). However, it is readily oxidised (49) and we believe it is unlikely

322 to be stable in rice flood waters or in the oxidised rhizosphere of rice roots. We tested the

323 hypothesis that selenourea could be taken up by rice plants in experiment 2, where pure

324 selenourea was applied to flood waters and persistence in floodwater determined, as well as

325 translocation to the xylem of rice plants growing under submerged conditions. While addition

326 of selenourea resulted in higher concentrations of $\mathrm{Se}$ in floodwater (compared to $\mathrm{SeO}_{4}{ }^{-2}-$

327 enriched UAN and urea) 1 day after application, it did not persist and Se was not detectable

328 in floodwater 10 days after fertilizer application (Table 6). Concentrations of Se in rice xylem

329 sap was highest with selenourea 1 day after fertilizer application, but 9 days later Se

330 concentrations in rice xylem sap were highest with $\mathrm{SeO}_{4}{ }^{-2}$-enriched urea granule treatment

331 (Table 5).

332

333

334 Selenium speciation in rice grain

335 In this study, the $\mathrm{SeO}_{4}{ }^{-2}$-enriched urea treatment had significantly higher concentrations of Se

336 in grains and husks than the other treatments. Therefore, rice grain samples from this

337 treatment were used for speciation studies by HPLC-ICP-MS. Enzymatic hydrolysis using

338 Protease XIV extracted $93 \pm 7 \%$ of the total Se present in the grain samples. The results of

339 the speciation analysis showed that $\mathrm{SeM}$ was the predominant species in grains of the $\mathrm{SeO}_{4}{ }^{-2}-$

340 enriched urea treatment (Figure 1). Quantitative data from the HPLC-ICP-MS analysis

341 (column recovery $\sim 90-100 \%$ ) indicate that SeM comprised over $90 \%$ and $\mathrm{SeOM} \sim 9 \%$ of

342 the total extracted grain Se. Similar results have been reported elsewhere (50). Our results

343 clearly show that applied inorganic $\mathrm{Se}\left(\mathrm{SeO}_{4}{ }^{-2}\right)$ accumulates in the rice grains as organic Se in 
344 the form of SeM which is more bio-available for humans than inorganic Se species (9). The

$345 \mathrm{SeO}_{4}{ }^{-2}$-enriched urea treatment did not cause the accumulation of different Se species than 346 those expected with a foliar or fluid $\mathrm{SeO}_{4}{ }^{-2}$ fertilizer.

348 In summary, differences in Se accumulation in rice plants were a function of the species of 349 applied Se, time of application, method of application and soil moisture regime. More Se 350 accumulated in rice plants when $\mathrm{SeO}_{4}{ }^{-2}$ was the $\mathrm{Se}$ species used in fertilizer in all water 351 regimes. This study confirmed previous findings that Se application pre-planting is not an 352 effective method of enhancing accumulation of Se in rice plants. Heading was the best time 353 for Se application. For both aerobic and submerged rice pots, Se fertilizer applied at the 354 heading stage, as $\mathrm{SeO}_{4}{ }^{-2}$-enriched urea was extremely effective as an agronomic 355 biofortification strategy. Selenium accumulation in rice plants decreased from rice roots in 356 the order grains $>$ leaves $>$ culms and husks. Drainage pre-harvest caused increased Se 357 accumulation in/on rice roots, possibly through adsorption onto iron plaque. Selenium in the 358 rice grains accumulated from application of $\mathrm{SeO}_{4}{ }^{-2}$-enriched urea was mainly in the form of 359 SeM which is highly bioavailable. Coating or incorporation of $\mathrm{SeO}_{4}^{-2}$ onto urea is simple and 360 inexpensive, and as farmers often apply a side dressing of urea to floodwaters during crop 361 growth, the practice is a simple and extremely effective way to supply Se to crops and to

362 biofortify grains with bioavailable Se. Further studies are needed to confirm the effectiveness

363 of this fertilizer strategy under field conditions and to understand the mechanisms responsible 364 for the enhancement of Se uptake observed with this fertilizer combination.

365

366 Abbreviations Used

367 FC- field capacity

368 DW- dry weight 
370 Acknowledgements

371 We thank Gillian Cozen for assistance during the pot trial. The authors are grateful for

372 financial support from AUSAid, Commonwealth Government of Australia.

LITERATURE CITED

376 1. Li, H. F.; McGrath, S. P.; Zhao., F.-J., Selenium uptake, translocation and speciation in 377 wheat supplied with selenate or selenite. New Phytologist 2008, (178), 92-102.

378 2. Grant, T. D.; Maria., M.-B.; LeDuc, D.; Fricke, M. W.; Terry, N.; Caruso, J. A., 379 Identification and characterization of Se-methyl selenomethionine in Brassia juncea $380 \quad$ roots. J. Chromatography 2004, 1026, 159-166.

381 3. Combs, G. F., Selenium in global food systems. Br.J.Nutr. 2001, 85, 517-547.

382 4. Lyons, G. H.; Judson, G. J.; Ortiz-Monasterio, I.; Genc, Y.; Stangoulis, J. C. R.; 383 Graham, R. D., Selenium in Australia: Selenium status and biofortification of wheat for 384 better health. Journal of Trace Elements in Medicine and Biology. Second International 385 Symposium on Trace Elements and Minerals in Medicine and Biology 2005, 19, (1), $386 \quad 75-82$

387 5. Broadley, M., R; white, P. J.; RosieJ.Bryson, Biofortification of UK food crops with 388 selenium. In Nutritional society, 2006; Vol. 65, pp 169-181.

389 6. Liu, Q.; Wang, D. J.; Jiang, X. J.; Cao, Z. H., Effects of the interactions between 390 selenium and phosphorus on the growth and selenium accumulation in rice (Oryza 391 sativa). Environ. Geochem. Health 2004, 26, (2).

392 7. Zhang, L. H.; Shi, W. M.; Wang, X. C., Difference in selenium accumulation in shoots 393 of two rice cultivars. Pedosphere 2006, 16, (5), 646-653. 
394 8. Mikkelsen, R. L., Page, A.L.,Bingham F.T., Factors affecting selenium accumulation 395 by agricultural crops. In Selenium in agriculture and the environment, L.W., J., Ed. $396 \quad$ SSSA special publication: Madison, 1989; $\mathrm{p} 234$.

397 9. Li, H.-F.; Lombi, E.; Stroud, J. L.; McGrath, S. P.; Zhao, F. J., Selenium speciation in 398 soil and rice: influence of water management and Se fertilization. J. Ag. Food Chem. $399 \quad 2010,58,(22), 11837-11843$.

400 10. Datta, S. K. D., Principles and practices of rice production. John Wiley \& Sons: New $401 \quad$ York, Chichester, Brisbane, Toronto, 1981; p 618.

402 11. Sharma, S.; Bansal, A.; Dhillon, S. K.; Dhillon, K. S., Comparative effects of selenate 403 and selenite on growth and biochemical composition of rapeseed (Brassica napus l.). $404 \quad$ Plant Soil 2010, 329, (1-2), 339-348.

405 12. Cartes, P.; Gianfreda, L.; Mora, M. L., Uptake of selenium and its antioxidant activity 406 in ryegrass when applied as selenate and selenite forms. Plant Soil 2005, 276, (1-2), $407 \quad 359-367$.

408 13. Barrow, N. J.; Whelan, B. R., Testing mechanistic model. VII. The effects of pH and 409 electrlyte on the reaction of selenite and selenate with a soil. J. Soil Sci. 1989, 40, 17$410 \quad 28$.

411 14. Gupta, U. C.; Winter, K. A.; Sanderson, Selenium content of barley as influenced by 412 selenite-enriched and selenate-enriched fertilizers. Commun. Soil. Sci. Plant Anal. $413 \quad$ 1993, 24, (11-12), 1165-1170.

414 15. Mikkelsen, R.; Mikkelsen., D. S.; Abshahi, A., Effects of soil flooding on selenium 415 transformation and accumulation by rice. Soil Sci. Soc. Am. J. 1989, 53, 122-127.

416 16. Barrow, N. J.; Whelan, B. R., Testing a mechanistic model .8. The effects of time and 417 temperature of incubation on the sorption and subsequent desorption of selenite and 418 selenate by a soil. J.Soil Sci. 1989, 40, (1), 29-37. 
419 17. Jayaweera, G. R.; Bigger, J. W., Role of redox in chemical transformation of selenium in soils. Soil Sci. Soc. Am. J. 1996, 60, 1056-1063.

421 18. Kápolna, E.; Hillestrøm, P. R.; Laursen, K. H.; Husted, S.; Larsen, E. H., Effect of foliar application of selenium on its uptake and speciation in carrot. Food Chem. 2009, $115,(4), 1357-1363$.

19. Chen, L.; Yang, F.; Xu, J.; Hu, Y.; Hu, Q.; Zhang, Y.; Pan, G., Determination of

20. Qiuhui, H.; Licheng, C.; Juan, X.; Yanling, Z.; Genxing, P., Determination of selenium concentration in rice and the effect of foliar application of Se-enriched fertiliser or sodium selenite on the selenium content of rice. J. Sci. Food and Agric. 2002, 82, (8), 869-872.

21. Premarathna, H. L.; McLaughlin, M. J.; Kirby, J. K.; Hettiarachchi, G. M.; Beak, D.; Samuel, S.; Chittleborough, D., Potential availability of fertilizer selenium in field capacity and submerged soils. Soil Sci. Soc. Am. J. 2010, 74, (5), 1589-1596.

22. Premarathna.H.L; Mike J. McLaughlin .; Ganga Hettiarachchi .; Jason Kirby .; Samuel Stacey ., David Chittleborough, Potential Availability of Fertiliser Selenium in Soils during Flooding and Subsequent Aeration. World soil congress 2010, August 1-5 Brisbane Australia.

440

23. Collins, R. N.; Tran, N. D.; Bakkaus, E.; Avoscan, L.; Gouget, B., Assessment of isotope exchange methodology to determine the sorption coefficient and isotopically exchangeable concentration of selenium in soils and sediments. Environ. Sci. Technol. 2006, 40, (24), 7778-7783.

24. Sors, T. G.; Ellis, D. R.; Salt, D. E., Selenium uptake, translocation, assimilation and metabolic fate in plants. Photosynthesis Research 2005, 86, (3), 373-389. 
25. Arvy, M. P., Transport and redistribution of selenium in the bean plant (Phaseolusvulgaris). J. Exp. Bot. 1993, 44, (263), 1083-1087.

26. Clark, L. C. J.; Turnbull, B. W.; Slate, E. H.; Chalker, D. K.; Chow, J.; Davis, L. S.; Glover, R. A.; Graham, G. F.; Gross, E. G.; Krongrad, A.; Lesher, J. L.; Park, H. K.;

27. Kirby, J. K.; Lyons, G. H.; Karkkaainen, M. P., Selenium speciation and bio availability in biofortified products using species-unspecific isotope dilution and reverse phase ion pairing- inductivity coupled plasma mass spectrometry. J. Agric. Food Chem. 2008, 56, 1772-1779.

28. Rayment, G. E.; Higginson, F. R., Australian laboratory handbook of soil and water chemical methods. Inkarta Press, Melbourne: 1992.

29. Matejovic, I., Determination of Carbon and Nitrogen in samples of various soils by the dry combustion. Comm.Soil.Sci.Plant Anal 1997, 28, 1499-1511.

30. Gunawardena, T. A.; Fukai, S.; Blamey, F. P. C., Low temperature induced spikelet sterility in rice. I. Nitrogen fertilisation and sensitive reproductive period. Aust.J.Soil Res. 2003, 54, 937-946.

31. Hu, Q.; Chen, L.; Xu, J.; Yang, F.; Zhang, Y.; Pan, G., Determination of selenium concentration in rice and effect of foliar application of Se-enriched fertiliser or sodium selenite on the selenium content of rice. J. Sci. Food Agric. 2002, 82, (8), 869.

32. Stadlober, M.; Sager, M.; Irgolic, K. J., Effects of selenate supplemented fertilisation on the selenium level of cereals- identification and quantification of selenium compounds. Food Chemistry 2001, 73, 357-366. 
33. Li, H.-F.; Steve, P. M.; Fang-Jie, Z., Selenium uptake, translocation and speciation in wheat supplied with selenate or selenite. New Phytologist 2008, 178, (1), 92-102.

34. Yoshida, M.; Yasumoto, K., Selenium contents of rice grown at various sites in Japan. Journal of Food Composition and Analysis 1987, 1, (1), 71-75.

35. Geering, R. H.; Cary, E. E.; Jones, L. P. H.; Allaway, W. H., Solubility and redox criteria for the possible forms of selenium in soils. Soil Sci. Soc. Am. J. 1968, 32, 35-40.

36. Neal, R. J., Selenium. In Heavy metals in soil, J, A. B., Ed. Blackie Academic and Professional: Reading, 1995; p 368.

37. Dhillon, K. S.; Dhillon, S. K., Selenium accumulation by sequentially grown wheat and rice as influenced by gypsum application in a seleniferous soil. Plant and Soil 2000, $227,(1), 243-248$.

38. Gissel-Nielsen, G.; Bisbjerg, B., The uptake of applied selenium by agricultural plants; The utilization of various selenium compounds. Plant soil 1970, 32, 382-396.

39. Lyons, G. H.; Jim, L.; Michelle, F. L.; Robert, E. H.; Dot , B.; James, C. R. S.; Robin, D. G., High-selenium wheat: Agronomic biofortification strategies to improve human nutrition. Food, Agric.Environ. 2004, 2, (1), 171-178.

40. Qiuhui Hu, L. C., Juan Xu, Yanling Zhang, Genxing Pan,, Determination of selenium concentration in rice and the effect of foliar application of Se-enriched fertiliser or sodium selenite on the selenium content of rice. Journal of the Science of Food and Agriculture 2002, 82, (8), 869-872.

41. Cao, Z. H.; Wang, X. C.; Yao, D. H.; Zhang, X. L.; Wong, M. H., Selenium geochemistry of paddy soils in Yangtze river delta. Environ. International 2001, 26, 335-339. 
42. Liang, Y.; Zhu, Y. G.; Xia, Y.; Li, Z.; Ma, Y., Iron plaque enhances phosphorus uptake by rice (Oryza sativa) growing under varying phosphorus and iron concentrations. Annals of Applied Biology 2006, 149, 305-312.

43. Zhou, X.-B.; Shi, W.-M., Effect of root surface iron plaque on Se translocation and uptake by Fe deficient rice. Pedosphere 2007, 17, (5), 580-587.

44. Kirkby, E. A.; Mengel, K., Ionic Balance in Different Tissues of the Tomato Plant in Relation to Nitrate, Urea, or Ammonium Nutrition. Plant Physiol 1967, 42, (1), 6-14.

45. Thien, S. J.; McFee, W. W., Influence of nitrogen on phosphorus absorption and translocation in zea mays. Soil Sci. Soc. Am. J. 1970, 34, (1), 87-90.

46. Cakmak, I.; Pfeiffer, W. M. B., Biofortification of durum wheat with zinc and iron. Cereal Chem. 2010, 87, 10-20.

47. Tam, S. C.; Chow, A. T.; Hadley, D., Effects of organic-component on the immobilization of selenium on iron oxyhydroxide. Sci. Total Environ. 1995, 164, (1), $1-7$.

48. Kronrad, L.; Hladik, V., A method for preparation of selenourea- ${ }^{75}$ Se. Int .J. Applied Rad. Isotopes 1972, 23, 237.

49. Zheng, J.; Shibata, Y.; Tanaka, A., Study of the stability of selenium compounds in human urine and determination by mixed ion-pair reversed-phase chromatography with ICP-MS detection. Anal. Bioanal. Chem. 2002, 374, (2), 348-353.

50. Williams, P. N.; Lombi, E.; Sun, G.-X.; Scheckel, K.; Zhu, Y.-G.; Feng, X.; Zhu, J.; Carey, A.-M.; Adomako, E.; Lawgali, Y.; Deacon, C.; Meharg, A. A., Selenium characterization in the global rice supply chain. Environ. Sci .Technol. 2009, 43, (15), 6024-6030. 
518 Figure captions

519 Figure 1. Selenium speciation in protease extracted rice grains of plants growing on pots

520 treated with $\mathrm{SeO}_{4}{ }^{2-}$-enriched urea granules applied at heading.

521

522

523

524

525

526

527

528

529

530

531

532

533

534

535

536

537

538

539

540

541

542 
543 Tables

544 Table 1. Operating conditions for HPLC-ICP-MS

Isocratic chromatographic parameters

\begin{tabular}{ll} 
Column & $\begin{array}{l}\text { Hamilton PRP-X100 anion exchange column } \\
(\text { Phenomenex })(250 \times 4.6 \mathrm{~mm}, 10 \mathrm{um})\end{array}$ \\
Mobile phase & $10 \mathrm{mM}$ Citric acid buffer $\%$ (v/v) methanol \\
$\mathrm{pH}$ & $5.5 \mathrm{pH}$ was adjusted using $\mathrm{NH}_{3}$ solution \\
Column temperature $\left({ }^{\circ} \mathrm{C}\right)$ & 25 \\
Flow rate $\left(\mathrm{ml} \mathrm{min}{ }^{-1}\right)$ & 1.0 \\
Injection volume $(\mu \mathrm{l})$ & 50 \\
\hline CP-MS parameters $($ Agilent $7500 \mathrm{ce})$ & \\
& \\
Isotopes monitored & ${ }^{76} \mathrm{Se},{ }^{77} \mathrm{Se},{ }^{78} \mathrm{Se}$ and ${ }^{82} \mathrm{Se}$, \\
Total analysis time(s) & 900
\end{tabular}

545

546

547

548 
549 Table 2. Effect of applied Se species, method of application and water management on grain and husk Se concentrations $(\mathrm{n}=3)^{\#}$

\begin{tabular}{|c|c|c|c|c|c|c|c|}
\hline \multirow[t]{2}{*}{$\begin{array}{l}\text { Moisture } \\
\text { treatment }\end{array}$} & \multirow[t]{2}{*}{ Se application method } & \multicolumn{3}{|c|}{$\begin{array}{l}\text { Grain Se concentration } \\
\qquad\left(\mathrm{mg} \mathrm{kg}^{-1}\right)^{\#}\end{array}$} & \multicolumn{3}{|c|}{$\begin{array}{l}\text { Husk Se concentration } \\
\qquad\left(\mathrm{mg} \mathrm{kg}^{-1}\right)^{\#}\end{array}$} \\
\hline & & $\mathrm{SeO}_{3}^{-2}$ & $\mathrm{SeO}_{4}^{-2}$ & control & $\mathrm{SeO}_{3}{ }^{-2}$ & $\mathrm{SeO}_{4}{ }^{-2}$ & control \\
\hline \multirow[t]{4}{*}{$\mathrm{FC}$} & At soil preparation & $0.059^{\mathrm{a}}$ & $0.079^{\mathrm{abcd}}$ & $0.076^{\mathrm{abc}}$ & $0.025^{\mathrm{a}}$ & $0.029^{\mathrm{ab}}$ & $0.030^{\mathrm{abc}}$ \\
\hline & Se -enriched urea at heading & $0.063^{\mathrm{ab}}$ & $0.405^{1 \mathrm{~m}}$ & & $0.030^{\mathrm{abc}}$ & $0.230^{\mathrm{kl}}$ & \\
\hline & Foliar at heading & $0.273^{\mathrm{kl}}$ & $0.150^{\mathrm{hij}}$ & & $0.157^{\mathrm{k}}$ & $0.050^{\mathrm{defg}}$ & \\
\hline & Fluid at heading & $0.094^{\text {bcdefg }}$ & $0.407^{\mathrm{m}}$ & & $0.055^{\mathrm{defgh}}$ & $0.208^{\mathrm{kl}}$ & \\
\hline \multirow[t]{4}{*}{ Submerged } & At soil preparation & $0.085^{\text {abcde }}$ & $0.092^{\text {bcdef }}$ & $0.086^{\text {abcde }}$ & $0.091^{\mathrm{j}}$ & $0.056^{\text {defghi }}$ & $0.036^{\mathrm{abcd}}$ \\
\hline & Se -enriched urea at heading & $0.117^{\text {defghi }}$ & $0.590^{\mathrm{m}}$ & & $0.077^{\text {ghij }}$ & $0.299^{1}$ & \\
\hline & Foliar at heading & $0.122^{\text {efghi }}$ & $0.105^{\text {cdefgh }}$ & & $0.090^{\operatorname{lmno}}$ & $0.084^{\mathrm{hij}}$ & \\
\hline & Fluid at heading & $0.089^{\text {abcde }}$ & $0.166^{\mathrm{ij}}$ & & $0.046^{\text {cdef }}$ & $0.071^{\text {fghij }}$ & \\
\hline \multirow{4}{*}{$\begin{array}{l}\text { Submerged/ } \\
\text { drained }\end{array}$} & At soil preparation & $0.082^{\text {abcde }}$ & $0.092^{\text {bcdef }}$ & $0.097^{\text {cdefg }}$ & $0.046^{\text {cdef }}$ & $0.046^{\text {cdef }}$ & $0.043^{\text {bcde }}$ \\
\hline & Se -enriched urea at heading & $0.138^{\text {ghij }}$ & $0.485^{\mathrm{m}}$ & & $0.063^{\text {efghij }}$ & $0.295^{1}$ & \\
\hline & Foliar at heading & $0.136^{\text {fghij }}$ & $0.176^{\mathrm{ij}}$ & & $0.068^{\text {fghij }}$ & $0.080^{\mathrm{hij}}$ & \\
\hline & Fluid at heading & $0.109^{\text {cdefgh }}$ & $0.189^{\mathrm{jk}}$ & & $0.056^{\text {defghi }}$ & $0.086^{\mathrm{ij}}$ & \\
\hline
\end{tabular}

$550{ }^{\#}$ Different letters in the table for grain and husk Se concentrations separately are significantly different for the three way interaction of Se

551 application method $\times$ applied Se species $\times$ water management. 
553 Table 3. ANOVA table for the statistical analysis of grain Se concentrations

\begin{tabular}{|c|c|c|c|c|c|}
\hline Source of variance & $\mathrm{DF}$ & SS & MS & v.r & F.prob \\
\hline Applied Se species (C) & 2 & 1.27325 & 0.63663 & 54.17 & $<0.001$ \\
\hline $\mathrm{A} \times \mathrm{C}$ & 2 & 1.53315 & 0.76658 & 65.22 & $<0.001$ \\
\hline $\mathrm{B} \times \mathrm{C}$ & 4 & 0.03292 & 0.00823 & 0.70 & 0.595 \\
\hline $\mathrm{A} \times \mathrm{B} \times \mathrm{C}$ & 4 & 0.27580 & 0.06895 & 5.87 & $<0.001$ \\
\hline
\end{tabular}

554 
Table 4. Effect of applied Se species, method of application and water management on leaf and culm Se concentrations $(n=3)$

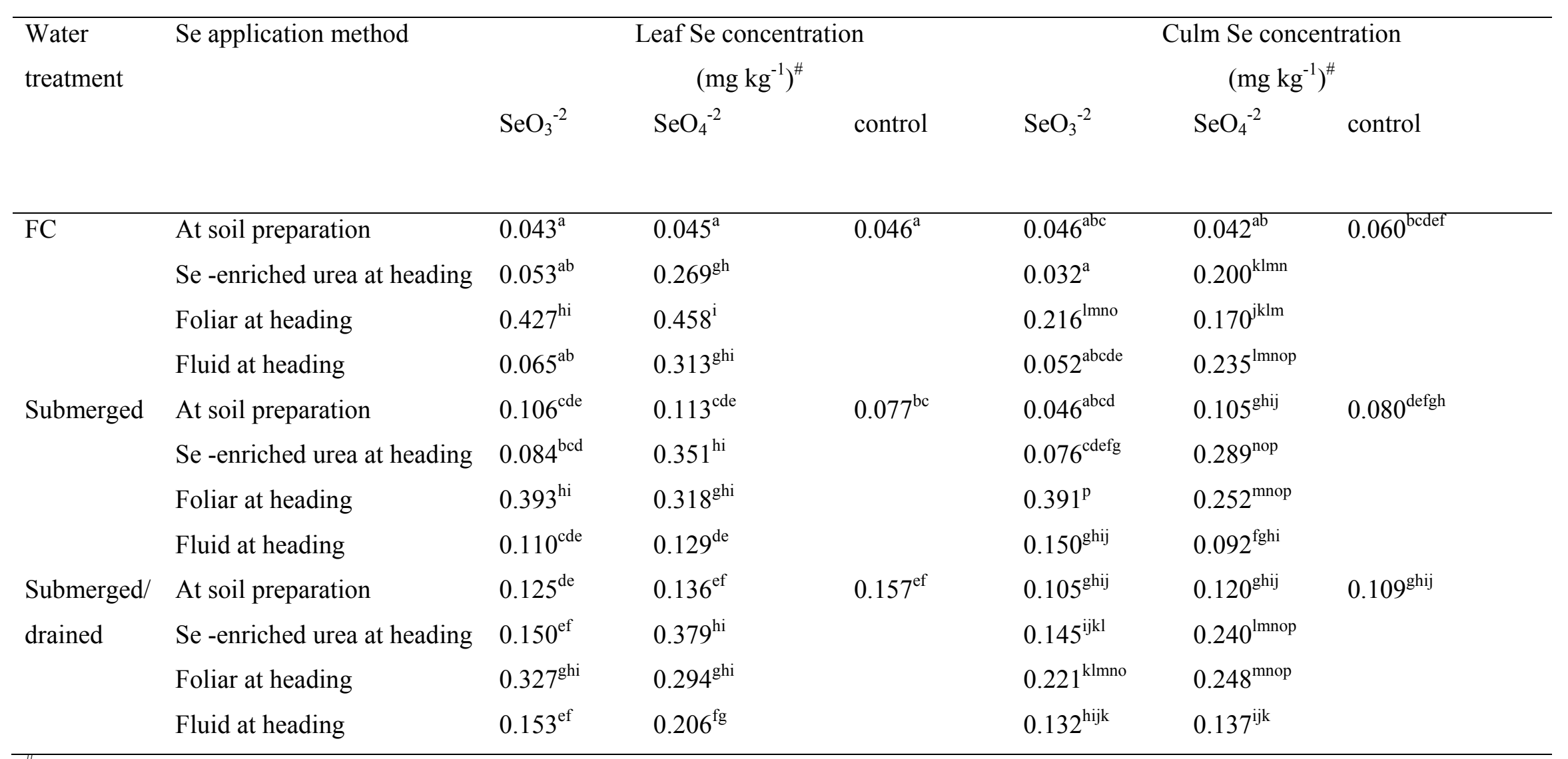

$560{ }^{\#}$ Different letters in the table for leaf and culm and concentrations separately are significantly different for the three way interaction of Se

561 application method $\times$ applied Se species $\times$ water management. 
563 Table 5. Effect of applied Se species, method of application and water management on root

564 Se concentrations $(\mathrm{n}=3)$

\begin{tabular}{|c|c|c|c|c|}
\hline \multirow[t]{4}{*}{ Water management } & \multirow[t]{4}{*}{ Se application method } & \multicolumn{3}{|c|}{ Root Se concentration } \\
\hline & & \multirow{3}{*}{$\mathrm{SeO}_{3}^{-2}$} & \multicolumn{2}{|c|}{$\left(\mathrm{mg} \mathrm{kg}^{-1}\right)^{\#}$} \\
\hline & & & $\mathrm{SeO}_{4}^{-2}$ & Control \\
\hline & & & & 1 \\
\hline \multirow[t]{4}{*}{$\mathrm{FC}$} & At soil preparation & $0.208^{\mathrm{ab}}$ & $0.143^{\mathrm{a}}$ & $0.173^{\mathrm{a}}$ \\
\hline & Se -enriched urea at heading & $0.193^{\mathrm{a}}$ & $0.429^{\text {def }}$ & \\
\hline & Foliar at heading & $0.163^{\mathrm{a}}$ & $0.175^{\mathrm{a}}$ & \\
\hline & Fluid at heading & $0.356^{\text {cde }}$ & $0.416^{\text {cdef }}$ & \\
\hline \multirow[t]{4}{*}{ Submerged } & At soil preparation & $0.441^{\mathrm{ef}}$ & $0.387^{\text {cdef }}$ & $0.311^{\mathrm{bc}}$ \\
\hline & Se -enriched urea at heading & $0.496^{\mathrm{f}}$ & $0.499^{\mathrm{f}}$ & \\
\hline & Foliar at heading & $0.317^{\text {bcd }}$ & $0.371^{\text {cde }}$ & \\
\hline & Fluid at heading & $0.432^{\mathrm{ef}}$ & $0.428^{\mathrm{def}}$ & \\
\hline \multirow[t]{4}{*}{ Submerged/drained } & At soil preparation & $0.780^{\text {gh }}$ & $0.768^{\mathrm{gh}}$ & $0.219^{\mathrm{ab}}$ \\
\hline & Se -enriched urea at heading & $1.008^{\mathrm{j}}$ & $0.863^{\mathrm{hi}}$ & \\
\hline & Foliar at heading & $0.678^{\mathrm{g}}$ & $0.812^{\mathrm{h}}$ & \\
\hline & Fluid at heading & $0.940^{\mathrm{ij}}$ & $0.853^{\text {hi }}$ & \\
\hline
\end{tabular}

${ }^{\#}$ Different letters in the table for root concentrations are significantly different for the three-

566 way interaction of the Se application method $\times$ applied Se species $\times$ water management 567 treatment.

568 
571 Table 6. Selenium concentration in flood water and plant xylem sap collected at two times

572 during the second experiment

\begin{tabular}{llll}
\hline Selenium treatment & Sample location & $\begin{array}{l}1 \mathrm{~d} \text { after Se } \\
\text { application }\end{array}$ & $\begin{array}{l}10 \mathrm{~d} \text { after Se } \\
\text { application }\end{array}$ \\
\hline Se -enriched urea $10 \mu \mathrm{g} \mathrm{kg}^{-1}$ & Flood water & $0.33 \pm 0.05$ & $<0.20$ \\
Pure seleno-urea $10 \mu \mathrm{g} \mathrm{kg}^{-1}$ & & $1.47 \pm 0.05$ & $<0.20$ \\
$\mathrm{UAN}+$ Se $10 \mu \mathrm{g} \mathrm{kg}^{-1}$ & & $0.60 \pm 0.16$ & $<0.20$ \\
Control & & $<0.20$ & $<0.20$ \\
& & $8.40 \pm 0.85$ \\
Se -enriched urea $10 \mu \mathrm{g} \mathrm{kg}^{-1}$ & Xylem sap & $2.00 \pm 0.0$ & $5.00 \pm 1.41$ \\
Pure seleno-urea $10 \mu \mathrm{g} \mathrm{kg}^{-1}$ & & $3.33 \pm 1.09$ & $<0.2$ \\
UAN+ Se $10 \mu \mathrm{g} \mathrm{kg}^{-1}$ & $2.00 \pm 0.0$ & $<0.2$ \\
Control & $<0.20$ & \\
& & &
\end{tabular}


586 Figure 1

587

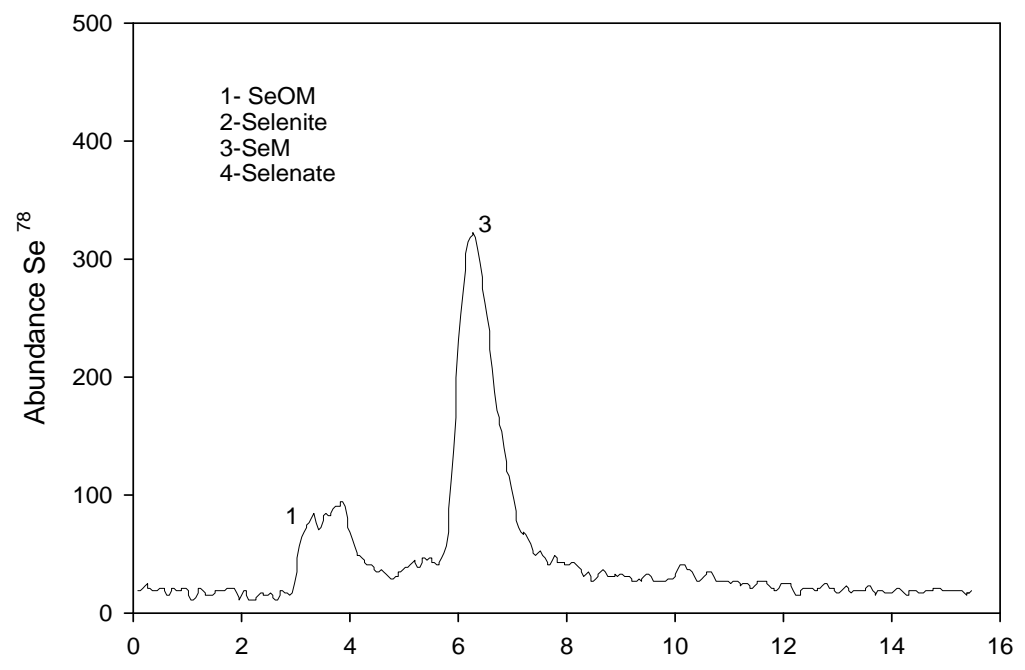

588

589

590

591

592

593

594

595

596

597

598

599

600

601

602

603

604

605

606

607

608

609

610

611

612

613

614

615

616

617

618

619 


\section{Supplementary information}

622

623 Table 1. Grain dry weights as a function of method of Se application and water management

$624 \quad(\mathrm{n}=3)$

\begin{tabular}{lccc}
\hline Application method & & \multicolumn{2}{c}{ Water Management $^{\#}$} \\
& FC & Submerged & Submerged \\
\hline Control & $7.27^{\mathrm{a}}$ & $14.86^{\text {hijklmno }}$ & $13.13^{\text {cdefg }}$ \\
Se applied at soil preparation & $10.69^{\text {bc }}$ & $13.44^{\text {defghijkl }}$ & $12.12^{\text {bcdef }}$ \\
Se enriched urea at heading & $12.03^{\text {bcde }}$ & $14.81^{\text {hijklmn }}$ & $13.20^{\text {cdefghi }}$ \\
Fluid Se at heading stage & $10.35^{\text {b }}$ & $14.09^{\text {defghijkl }}$ & $13.19^{\text {cdefgh }}$ \\
Foliar Se at heading stage & $11.72^{\text {bcd }}$ & $14.31^{\text {defghijklm }}$ & $13.72^{\text {defghijk }}$
\end{tabular}

$625{ }^{\#}$ Different superscript letters in the table are significantly different $(\mathrm{p} \leq 0.05)$ for the two way

626 interaction of the effect of water management $\times$ Se application method.

627

628

629

630

631

632

633

634 
636 Table 2. Nutrient contents in leaf and grain tissues from rice plants grown in control pots in 637 submerged and field capacity soils

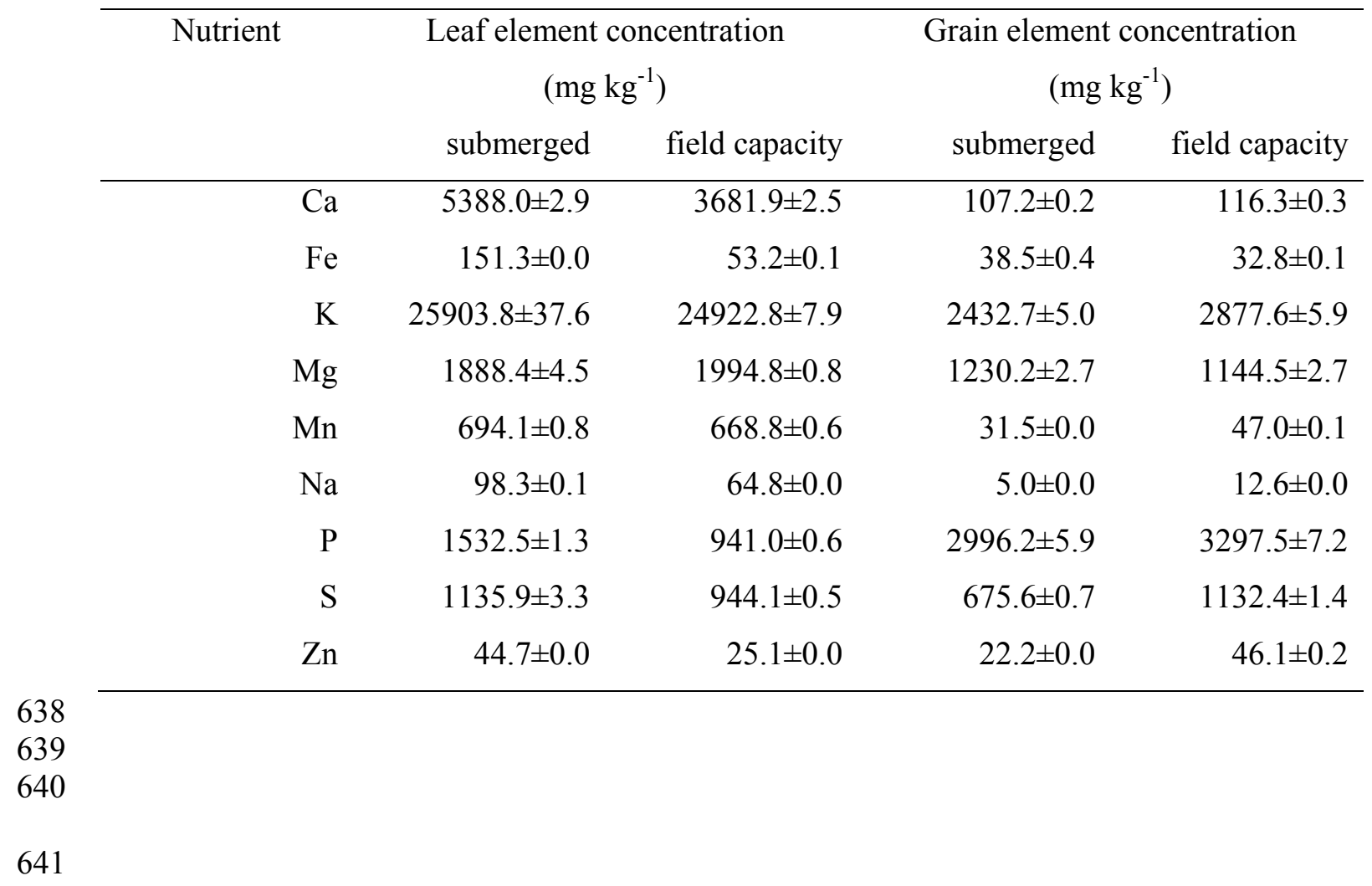

